\title{
Kondisi Kualitas Perairan untuk Mendukung Budidaya Lobster di Kabupaten Lombok Utara, Provinsi Nusa Tenggara Barat
}

\section{Conditions of Water Quality to Support Lobster Cultivation in North Lombok Regency, West Nusa Tenggara Province}

\author{
Muhammad Junaidi $^{1 *}$, Nurliah ${ }^{1}$ dan Fariq Azhar ${ }^{1}$ \\ ${ }^{1)}$ Program Studi Budidaya Perairan \\ Universitas Mataram, Jl. Majapahit No. 62 Mataram. Lombok, \\ Nusa Tenggara Barat, Indonesia, 83125 \\ *corresponding author, email: m.junaidi@unram.ac.id
}

Manuscript received: 04-25-2018. Accepted: 20-12-2018

\begin{abstract}
ABSTRAK
Lobster (Spiny lobster, Panulirus sp) merupakan komoditas yang bernilai ekonomis penting, sehingga perlu dikembangkan melalui budidaya. Kabupaten Lombok Utara memiliki sumberdaya pesisir dan laut yang potensial untuk pengembangan budidaya laut. Oleh karena itu, perlu dilakukan penelitian dengan untuk mengetahui kondisi kualitas perairan di Kabupaten Lombok Utara ProvinsiNusa Tenggara Barat guna mendukung pengembangan budidaya lobster (Panulirus sp).Pengumpulan data kualitas perairan dilakukan pada bulan Mei 2018. Sebanyak 23 stasiun yang tersebar secara acak sederhana telah dikumpulkan di lokasi penelitian. Parameter kualitas air yang dikumpulkan meliputi: suhu, salinitas, $\mathrm{pH}$, oksigen terlarut (DO), kecerahan, kekeruhan, nitrat $\left(\mathrm{NO}_{3^{-}}\right.$ $\mathrm{N})$, fosfat $\left(\mathrm{PO}_{4}-\mathrm{P}\right)$ dan plankton. Hasil penelitian menunjukkan bahwa kondisi perairan Kabupaten Lombok Utara masih memenuhi kisaran baku mutu atau nilai yang direkomendasikan untuk budidaya lobster. Berdasarkan analisis statistik multivariat yang digunakan dalam penelitian ini membagi lokasi penelitian menjadi tiga wilayah yang berbeda yaitu wilayah perairan bagian selatan yaitu sekitar Pantai Sire, wilayah bagian tengah di Kecamatan Tanjung dan Gangga dan wilayah bagian Utara yang lebih berhadapan dengan laut lepas. Hasil penelitian ini diharapkan dapat memberikan tambahan informasi guna mendukung pengembangan budidaya lobster di Kabupaten Lombok Utara.
\end{abstract}

Kata kunci: kekeruhan, plankton, salinitas, sumber daya pesisir

\begin{abstract}
Lobster (Spiny lobster, Panulirus $s p$ ) is an important economic value commodity, then it needs to be developed through cultivation. North Lombok Regency has potential coastal and coastal resources for the development of marine aquaculture. Therefore, this study was to determine the condition of water quality in North Lombok Regency, West Nusa Tenggara Province to support the development of lobster aquculture. Water quality data collection was carried out in May 2018. A total of 23 stations that were spread out in simple random locations were collected at the research location. Water quality parameters collected include: temperature, salinity, $\mathrm{pH}$, dissolved oxygen (DO), brightness, turbidity, nitrate $\left(\mathrm{NO}_{3}-\mathrm{N}\right)$, phosphate $\left(\mathrm{PO}_{4}-\mathrm{P}\right)$ and plankton. The results showed that the water conditions of North Lombok Regency still meet the range of quality standards or values recommended for lobster
\end{abstract}


cultivation. Based on analysis of the statistics multivariate used in this research divide research locations into three different regions, the waters of the south (Gulf Sire), middle parts in Tanjung and Gangga District, and the northern in off shore.The result of this research is expected to be able as additional information to support the development of the cultivation of spiny lobster in North Lombok Regency.

Key words: coastal resources, plankton, salinity, turbidity

\section{PENDAHULUAN}

Lobster (Spiny lobster, Panulirussp) atau udang karang merupakan salah satu jenis udang-udangan (Crustacea) yang bernilai ekonomis penting. Hal ini terlihat dari tinggi permintaan komoditas ini, baik untuk pasar lokal maupun sebagai komoditas ekspor, terutama ke negara-negara negara-negara dikawasan Asia Tenggara, Hongkong, Taiwan, China dan Jepang (Jones, 2010). Lobster memiliki daerah penyebaran yang cukup luas, menyebar di hampir seluruh perairan yang berkarang di dunia dari pantai timur Afrika, Jepang, Australia, Selandia Baru dan Indonesia (Holthuis, 1991). Menurut Romimohtarto dan Juwana (2007), di perairan Indonesia diperkirakan terdapat 7 species lobster marga Panulirus yang sering ditemukan dalam lingkungan yang berbeda antara lain P.homarus, $P$. ornatus, $P$. penicillatus, $P$.longiceps, $P$. polyphagus, $P$. versicolor, dan $P$. daypus. Namun yang potensial untuk dibudidayakan ada dua species yaitu $P$. homarus (lobster pasir) dan $P$. ornatus (lobster mutiara) (Jones, 2010; Junaidi et al., 2010; Junaidi et al., 2011).

Budidaya lobster dalam keramba jaring apung (KJA) mulai berkembang sejak tahun 2000 di perairan Lombok, Provinsi Nusa Tenggara Barat (Mustafa, 2013; Junaidi dan Heriati, 2017). Pada waktu itu, banyak ditemukan benih alam yang menempel pada pelampung dan material lain yang berkaitan dengan budidaya rumputlaut dan kerapu (Priyambodo dan Sarifin, 2008; Erlania et al, 2014), kemudian benih-benih tersebut diambil untuk kegiatan budidaya pembesaran (ongrowing culture) dalam KJA. Menurut Priambodo dan Jaya (2009), pada umumnya benih yang digunakan pada usaha pembesaran lobster diI ndonesia merupakan hasil tangkapan dari alam. Prospek budidaya lobster lebih besar dibandingkan dengan spesies lobster dari perairan iklim sedang (temperates pecies), karena faktor ketersediaan benih alam yang lebih besar, dan laju pertumbuhannya yang lebih tinggi (Jeffs andDavis, 2003).

Kabupaten Lombok Utara merupakan kabupaten pesisir yang memiliki potensi sumberdaya pesisir dan laut yang cukup besar. Terdapat tiga pulau kecil (gili) yang disingkat Gili Matra (Meno, Trawangan dan Air). Keindahan ekosistem terumbu karang, keanekaragaman jenis ikan, dan keindahan pantai di Gili Matra, sehingga merupakan destinasi wisata bahari yang terkenal sampai ke mancanegara. Selain dimanfaatkan sebagai kawasan wisata bahari, potensi sumberdaya pesisir dan laut Kabupaten Lombok Utara sebagian lainnya dimanfaatkan sebagai kawasan perikanan budidaya laut dan perikanan tangkap. Kegiatan budidaya laut yang sedang berkembang di Kabupaten Lombok Utara adalah budidaya laut dengan komoditas antara lain kerang mutiara, kerapu, bawal bintang, rumput laut dan lobster (KKP, 2014; Junaidi et al., 2018).

Arcenal (2004) menyatakan bahwa terdapat berbagai kriteria yang menjadi persyaratan, baik secara teknis maupun biologis untuk dapat mengembangkan suatu spesies potensial melalui budidaya laut. Untuk budidaya pembesaran lobster tidakjauh berbeda dengan 
persyaratan untukbudidaya biota laut pada umumnya (Setyono, 2006). Keberhasilan dan keberlanjutan usaha budidaya laut selain bergantung pada kondisi lingkungan, juga harus didukung oleh ketersediaan benih yang berkesinambungan. Menurut Erlania et al., (2014), ketersediaan benih lobster yang berlimpah di alam dapat dikelola melalui teknologi budidaya pembesaran yang baik, sehingga dapat memberikan nilai tambah yang jauh lebih besar bagi perekonomian masyarakat pesisir dibandingkan hanya dengan penjualan benih hasil tangkapan.

Menurut Thao (2012) setiap stadia hidup lobster berasosiasi dengan kondisi lingkungan yang spesifik dan memperlihatkan daya adaptasi yang nyata, dimana stadia larvaphyllosoma mengapung pada permukaan air dan akan terbawa oleh gelombang, arus, dan angin. Stadia larva puerulus dapat berenang bebas dan berpindah ke daerah dangkal dan terlindung; juvenile hidup di sekitar area pantai yang terlindung oleh rumput laut dan karang dimana terdapat makanandandapat terhindardaripredator. Dengan demikian, ketersedian dan kelimpahan benih lobster di alam selain dipengaruhi oleh pergerakan arus, gelombang, dan topografi perairan, juga sangat dipengaruhi oleh kondisi lingkungan perairan (Erlania et al., 2014). Selain itu, stadia hidup lobster terutana pada stadia larva phyllosoma dan puerulus sumber makanan utamanya berasal dari alam (plankton) (Junaidi et al., 2011), maka tingkat kesuburan perairan merupakan parameter penting yang harus diperhatikan.Sehubungan dengan hal tersebut, data dan informasi tentang kondisi kualitas perairan di lokasi budidaya lobster sangatlah diperlukan. Penelitian ini bertujuan untuk mengetahui kondisi kualitas perairan di Kabupaten Lombok Utara ProvinsiNusa Tenggara Barat guna mendukung pengembangan budidaya lobster (Panulirus sp).

\section{METODE PENELITIAN}

\section{Lokasi Penelitian}

Penelitian ini dilaksanakan pada bulan Mei 2018 di Perairan Kabupaten Lombok Utara, Provinsi Nusa Tenggara Barat (Gambar 1). Lokasi penelitian terbentang pada posisi $116^{\circ} 6^{\prime}$ $38^{\prime \prime}-116^{\circ} 14^{\prime} 33^{\prime \prime}$ BujurTimur dan 8 $14^{\prime} 42^{\prime \prime}-8^{\circ} 22^{\prime}$ 2" Lintang Selatan,yang mencakup empat kecamatan dari selatan ke utara yaitu Kecamatan Pemenang, Tanjung, Gangga, dan Kayangan Kabupaten Lombok Utara.

\section{Pengumpulan Data}

Pengumpulan data kualitas perairan dilakukan pada bulan Mei 2018. Sebanyak 23 stasiun yang tersebar secara acak sederhana (simple random sampling) (Clarkand Hosking,1986; Morain, 1999) telah dikumpulkan di lokasi penelitian. Setiap stasiun pengamatan dan pengambilan contoh ditentukan posisi koordinatnya dengan alat GPS (Global Positioning Systemt). Parameter kualitas air yang dikumpulkan meliputi: suhu, salinitas, $\mathrm{pH}$, oksigen terlarut (DO), kecerahan, kekeruhan, nitrat $\left(\mathrm{NO}_{3}-\mathrm{N}\right)$, fosfat $\left(\mathrm{PO}_{4}-\mathrm{P}\right)$ dan plankton. Parameter suhu, salinitas, $\mathrm{pH}$, DO, dan kecerahan diukur langsung di lapangan menggunakan refractometer, $\mathrm{pH}$-meter, oxy-meter, dan secci disk, sedangkan parameter lainnya dianalisis di laboratorium Bioekologi Program Studi Budidaya Perairan Universitas Mataram.Metode pengambilan, preservasi, dan analisis sampel air mengacu pada metode standar APHA (2005).

\section{Analisis Data}


Data kualitas perairan yang terkumpul kemudian dianalisis secara deskriptif dengan cara membandingkan dengan baku mutu dan kondisi ideal untuk pengembangan budidaya lobster(Tabel 1). Selanjutnya dilakukan analisis spasial untuk memetakan data kulitas perairan. Analisis spasial dilakukan dengan teknik interpolasi kriging (Siregar dan Selamat, 2009), yang terdapat dalam sofware Surfer 9 (Golden Software, Inc). Keunggulan interpolasi kriging dibandingkan teknik konturisasi lainnya adalah kemampuannya untuk mengkuantifikasi variansi dari nilai yang diestimasi sehingga tingkat presisi dari hasil estimasi dapat diketahui (Siregar dan Selamat, 2009; Hadi, 2013).

\section{Analisis Data}

Data kualitas perairan yang terkumpul kemudian dianalisis secara deskriptif dengan cara membandingkan dengan baku mutu dan kondisi ideal untuk pengembangan budidaya lobster(Tabel 1). Selanjutnya dilakukan analisis spasial untuk memetakan data kulitas perairan. Analisis spasial dilakukan dengan teknik interpolasi kriging (Siregar dan Selamat, 2009), yang terdapat dalam sofware Surfer 9 (Golden Software, Inc). Keunggulan interpolasi kriging dibandingkan teknik konturisasi lainnya adalah kemampuannya untuk mengkuantifikasi variansi dari nilai yang diestimasi sehingga tingkat presisi dari hasil estimasi dapat diketahui (Siregar dan Selamat, 2009; Hadi, 2013).

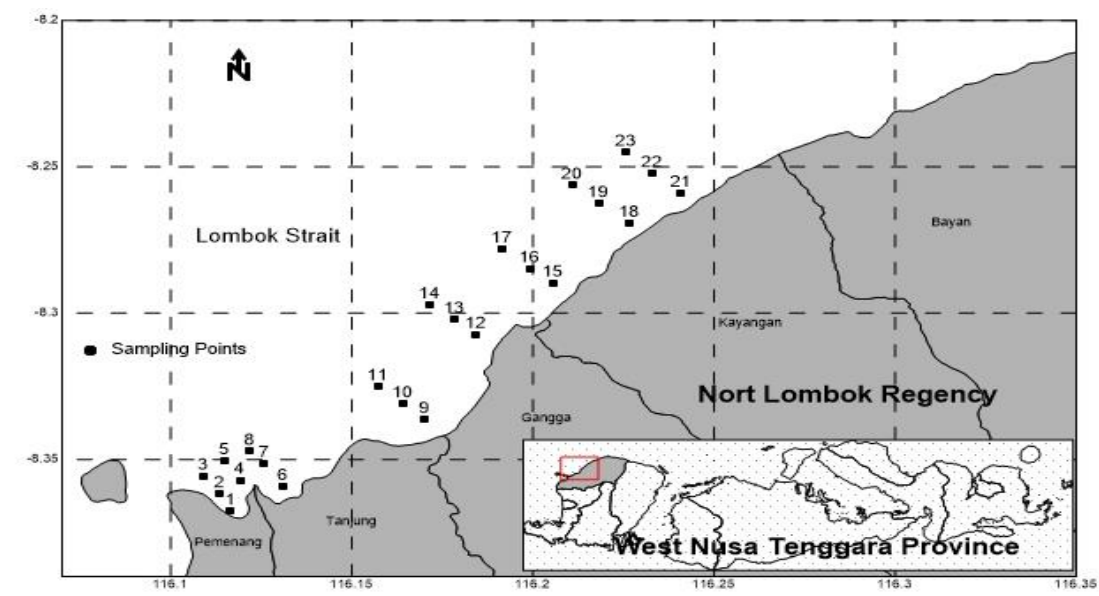

Gambar 1. Lokasi penelitian di Kabupaten Lombok Utara Provinsi Nusa Tenggara Barat dan sebaran stasiun pengamatan kualitas perairan

Tabel 1. Nilai parameter kualitas perairan untuk budidaya lobster

\begin{tabular}{llcc}
\hline Parameter & Satuan & Nilai ideal & Pustaka \\
\hline Suhu air & ${ }^{\circ} \mathrm{C}$ & $27-32$ & $1,2,3$ \\
Kecerahan & $\mathrm{m}$ & $>3$ & 4 \\
Kekeruhan & $\mathrm{NTU}$ & $<5$ & 4 \\
$\mathrm{pH}$ & & $7,0-8,5$ & $1,2,3$ \\
Salinitas & $\mathrm{ppt}$ & $30-35$ & 2,3 \\
Oksigen terlarut & $\mathrm{mg} / \mathrm{l}$ & $>5$ & $1,2,3,4$ \\
Nitrat $\left(\mathrm{NO}_{3}-\mathrm{N}\right)$ & $\mathrm{mg} / \mathrm{l}$ & $0-0,008$ & 4 \\
Fosfat $\left(\mathrm{PO}_{4}-\mathrm{P}\right)$ & $\mathrm{mg} / \mathrm{l}$ & $0-0,015$ & 4 \\
${ }^{1}$ FAO $(1989) ;{ }^{2} \mathrm{Chou}$ and Lee $(1997) ;{ }^{3}$ Szuster and Albasri $(2010) ;{ }^{4}$ MNKLH $(2004)$
\end{tabular}


Untuk melihat pengelompokan stasiun pengamatan berdasarkan karakteristik kualitas perairan digunakan analisis multivariat yang didasarkan pada analisis klaster (cluster analysis $=\mathrm{CA})$ dan analisis komponen utama(Principal Component Analysis $=\mathrm{PCA})$. Jika dalam analisis klaster yang digunakan sebagai data dasarnya adalah indeks kemiripan antar stasiun (Iscen et al., 2008; Kazi et al., 2009; Rachmatin, 2014), maka untuk perhitungan AKU konsep yang digunakan adalah jarak Euclidian (jumlah kuadrat perbedaan karakteristik pada data) (Isce et al., 2008; Soedibjo, 2008; Ismunarti, 2013). Analisis statistik ini dilakukan dengan menggunakan software XLSTAT addinsoft Microsoft Office Excel 2010.

\section{HASIL DAN PEMBAHASAN}

\section{Kondisi Kualitas Perairan}

Kualitasperairanmerupakanfaktorpenting yang perlu diperhatikan dalam rangka pemanfaatan lahan baik untuk kegiatan perikanan, pariwisata, pembangkit listrik, sumber air minum, ataupun aktivitas lainnya. Pemantauan kondisi kualitas perairan merupakan tahapan penting dalam pengelolaan dan pemanfaatan lahan guna mendukung keberlanjutan usaha yang dilakukan (GESAMP, 2001; Radiarta et al., 2013). Di Kabupaten Lombok Utara, selain dimanfaatkan sebagai Taman Wisata Peraairan Gili Matra seluas 29,54 km², potensi sumberdaya pesisir dan laut Kabupaten Lombok Utara sebagian lainnya dimanfaatkan sebagai kawasan perikanan budidaya dan perikanan tangkap. Kegiatan budidaya laut di perairan Kabupaten Lombok Utara sudah berlangsung dan terbatas pada beberapa sistem dan komoditas budidaya. Sistem budidaya yang digunakan adalah jaring apung dan rakit, sedangkan komoditas yang diusahakan mencakup ikan kerapu (Epinephelus sp), rumput laut (Euchema cottonii, kerang mutiara (Pinctada maxima) dan lobster (Panulirus sp)

Hasil pemantauan dan distribusi spasial kondisi kualitas perairan di lokasi penelitian ditampilkan pada Tabel 2 dan Gambar 2. Parameter fisik kualitas perairan (suhu, kecerahan dan kekeruhan) umumnya masih dalam kondisi yang baik untuk mendukung biota laut (Tabel 2). Hasil pengukuran suhu menunjukkan kisaran $30,7-31,7^{\circ} \mathrm{C}$ dengan nilai rata-rata $31,06^{\circ} \mathrm{C}$, kondisi suhu ini masih tergolong dalam kategori baik untuk budidaya lobster. Seperti yang dikemukakan olehFAO (1989); Chou and Lee (1997); Szuster and Albasri (2010)bahwa suhu air untuk kegiatan budidaya laut yaitu $26^{\circ} \mathrm{C}-32^{\circ} \mathrm{C}$. Kecerahan perairan di lokasi penelitian menunjukkan nilai yang sangat mendukung pertumbuhan biota laut sesuai baku mutu (MNLH, 2004) dengan nilai rata-rata 14,3 m(Tabel2).Kecerahan menunjukkan kemampuan penetrasi cahaya kedalam perairan. Tingkat penetrasi cahaya sangat dipengaruhi oleh partikel yang tersuspensi dan terlarut dalam air sehingga mengurangi laju fotosintesis. Tingkat kecerahan yang terukur sangat relatif terhadap kedalaman perairan. Sedangkan kekeruhan dapat menyebabkan efek negatif pada kualitas air, terutama kadar DO, BOD, suhu dan berdampak terhadap keragaman jenis ikan, akibat penurunan fotosintesis, populasi plankton, alga serta mikrofita (Makmur et al., 2012). Hasil pengukuran kekeruhan menunjukkankisaran0,13-0,45 NTUdengannilai rata-rata 0,3 NTU(Tabel2). Kisaran ini masih memenuhi nilai ambang batas baku mutu peruntukan biota laut yaitu 5 NTU (MNLH, 2004).

Kondisi derajat keasaman $(\mathrm{pH})$ hasil pengukuran lapangan memberikan gambaran bahwa kondisi $\mathrm{pH}$ di lokasi penelitian merupakan perairan yang cenderung basa dengan kisaran $\mathrm{pH}$ antara 8,0-8,2, hal ini menunjukkan bahwa perairan tersebut cukup ideal pengembangan budidaya laut dengan berbagai komoditas. Menurut FAO (1989) perairan 
dengan $\mathrm{pH}$ netral sampai sedikit basa merupakan perairan dengan kondisi yang ideal pengembangan budidaya laut dengan berbagai komoditas. Hasil pengukuran salinitas menunjukkankisaran29-32 ppt dengannilai rata-rata 30,5 ppt (Tabel2). Hal ini mengindikasikan bahwa perairan lokasi penelitian cenderung bersifat sebagai perairan pantai (coastal water) dari pada bersifat sebagai osenik (oceanic water) yang mempunyai nilai salinitas > 34,5 ppt sesuai klasifikasi Wyrtki (1961 dalam Simanjuntak, 2009).

Oksigen terlarut tercatat dengan kisaran cukup tinggi yaitu kisaran $6,8-8,7 \mathrm{mg} . \mathrm{l}^{-1}$ dan nilai rata-rata $7,46 \mathrm{mg} . \mathrm{l}^{-1}$. Nilai oksigen tersebut masih dikategorikan sesuai untuk perkembangan biota laut (MNKLH,2004). Kondisi oksigen terlarut di perairan dipengaruhi antara lain oleh suhu, salinitas, pergerakan massa air, tekanan atmosfir, kelimpahan fitoplankton dan tingkat saturasi oksigen sekelilingnya serta adanya pengadukan massa air oleh angin (Simanjuntak, 2009). Nitrat dan fosfat merupakan unsur hara yang memiliki peran sangat terhadap pembentukan sel jaringan jasad hidup organisme laut dan juga proses fotosintesi oleh fitoplankton (Paiki dan Kalor, 2017). Rata-rata kadar nitrat dan fosfat yang ditemukan di lokasi penelitian berturut-turut adalah $0,158 \mathrm{mg} \cdot \mathrm{l}^{-1}$, dan 0,033 mg. $\mathrm{l}^{-1}$ (Tabel 2). Kisaran nilai nitrat dan fosfat telah melampaui nilai ambang batas baku mutu peruntukan biota laut yaitu 5 NTU (MNLH, 2004). Tinggginya kandungan unsur hara ini dapat disebabkan oleh masuknya limbah domestik atau pertanian yang banyak mengandung nutrient. Daerah dekat muara sungai ataupun perairan dekat dengan perkampungan penduduk umumnya memiliki kadar nitrat, amoniak, dan fosfat yang tinggi.

Tabel 2. Kondisi kualitas perairan di Kabupaten Lombok Utara, Nusa Tenggara Barat

\begin{tabular}{llcccc}
\hline Peubah & Satuan & Kisaran & Rata-rata & $\begin{array}{c}\text { Standar } \\
\text { deviasi }\end{array}$ & Nilai Ideal \\
\hline Suhu air & ${ }^{\circ} \mathrm{C}$ & $30,7-31,7$ & 31,06 & 0,27 & $27-32$ \\
Kecerahan & $\mathrm{m}$ & $4,0-22,0$ & 14,3 & 5,3 & $>3$ \\
Kekeruhan & $\mathrm{NTU}$ & $0,13-0,45$ & 0,3 & 0,07 & $<5$ \\
pH & & $8,0-8,2$ & 8,09 & 0,07 & $7,0-8,5$ \\
Salinitas & $\mathrm{ppt}$ & $29-32$ & 30,5 & 0,8 & $30-35$ \\
Oksigen terlarut & $\mathrm{mg.1}$ & $6,8-8,7$ & 7,46 & 0,41 & $>5$ \\
Nitrat $\left(\mathrm{NO}_{3}-\mathrm{N}\right)$ & $\mathrm{mg.1}$ & $0,152-0,165$ & 0,158 & 0,0034 & $0-0,008$ \\
Fosfat $\left(\mathrm{PO}_{4}-\mathrm{P}\right)$ & $\mathrm{mg} \cdot \mathrm{l}^{-1}$ & $0,026-0,042$ & 0,033 & 0,0041 & $0-0,015$ \\
\hline
\end{tabular}

Secara umum perairan Kabupaten Lombok Utara merupakan kawasan potensial pengembangan budidaya laut. Karakteristik fisika-kimia perairan seperti $\mathrm{pH}$, salinitas, kecerahan, suhu, oksigen terlarut dan kekeruhan, masih memenuhi ambang batas baku mutu peruntukan biota laut, sedangkan nitrat dan fosfat telah melampaui baku mutu. Tingginya kadar nitrat dan fosfat selain dipengaruhi oleh external loading, budidaya lobster berpotensi sebagai penyumpang unsur hara dalam perairan dari pakan yang tidak termakan dan feses lobster yang dipelihara yang dapat menyebabkan penurunan kualitas perairan seperti yang terjadi di Teluk Ekas Provinsi Nusa Tenggara Barat (Junaidi, 2016). Sementara hasil analisis kelimpahan plankton di perairan Lombok Utara diperoleh kelimpahan total plankton adalah 6.760 ind. $\mathrm{L}^{-1}$ (kelimpahan fitoplankton 5.500 ind. $\mathrm{L}^{-1}$ dan zooplankton 1.260 ind. $\left.\mathrm{L}^{-1}\right)$. Berdasarkan nilai kelimpahan fitoplankton, perairan Lombok Utara dapatd 
igolongkan sebagai perairan mesotrofik (tingkat kesuburan sedang). Menurut Basmi (2000), ditinjau dari kelimpahan fitoplankton, suatu perairan dapat digolongkan sebagai perairan mesotrofik jika kelimpahan fitoplankton di perairan tersebut berkisar antara 2.00015.000 ind. $\mathrm{L}^{-1}$. Kondisi perairan yang demikian, sesuai untuk pertumbuhan benih lobster.

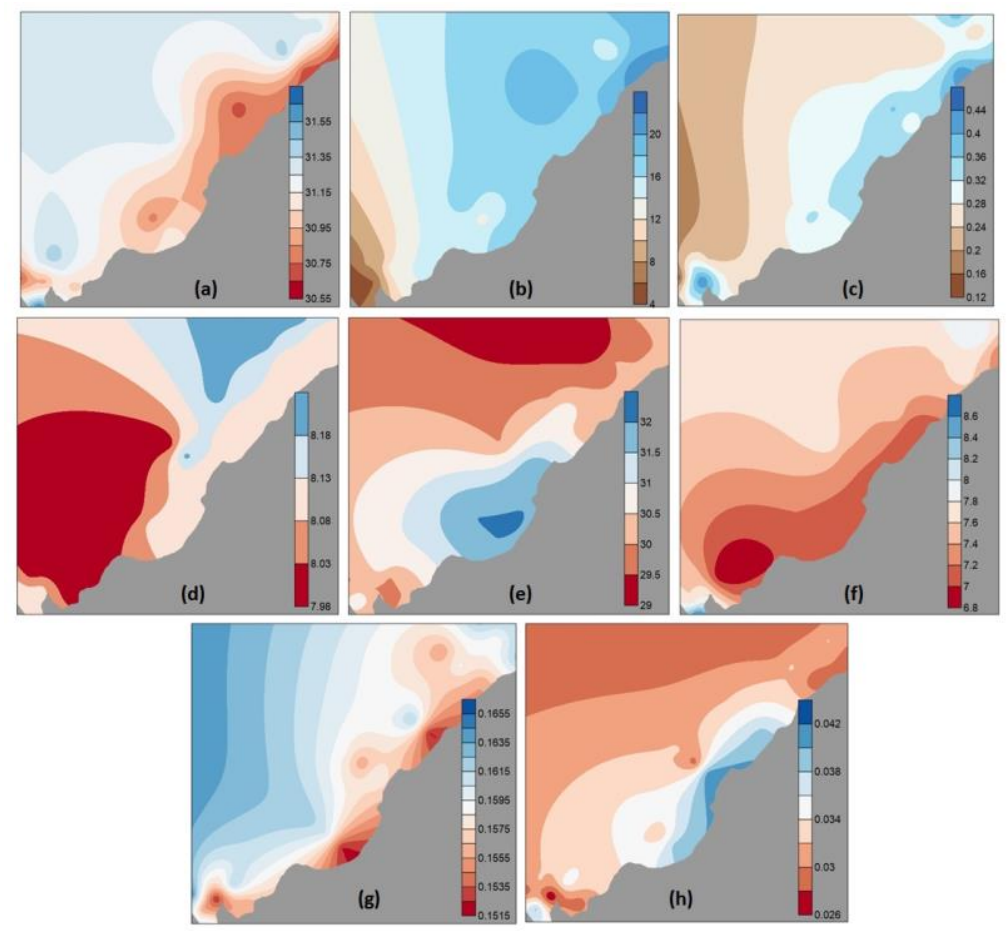

Gambar 2. Peta spasial parameter kualitas di perairan Kabupaten Lombok Utara, Nusa Tenggara Barat: (a) suhu air, (b) kecerahan, (c) kekeruhan, (d) pH, (e) salinitas, (f) oksigen terlarut, (g) nitrat, dan (h) fosfat

Kawasan perairan Kabupaten Lombok Utara sangat potensial untuk pengembangan budidaya lobster, asalkan diterapkan kaidah-kaidah dan strategi budidaya berkelanjutan. Strategis pengembangan budidaya berkelanjutan yang dapat diterapkan antara lain budidaya terpadu (integrated marine farming), atau mengalokasikan sumberdaya budidaya dan akua input pada lokasi yang layak dan tidak melebihi daya dukung lingkungan perairan, sehingga diharapkan akan memberikan peluang keberlanjutan usaha budidaya (Junaidi, 2016).

\section{Analisis Multivariat}

Analisis klaster (CA) digunakan untuk mendeteksi tingkat kesamaan kelompok karakteristik lingkungan perairan pada 23 stasiun pengamatan kualitas perairan. Gambar 3 menunjukkan dendogram hasil CA di lokasi penelitian. Berdasarkan CA, 23 stasiun pengamatan kualitas air secara signifikan dikelompokkan menjadi tiga klaster. Klaster 1 terdiri atas stasiun 1-5 dan 8. Klaster ini berada pada kawasan bagian selatan lokasi penelitian yaitu di sekitar Pantai Sire yang merupakan lokasi pariwisata. Klaster ini dicirikan dengan karakteristik perairan memiliki nilai kecerahan yang rendah (Gambar 2b). Nilai kecerahan rendah bukan akibat tingginya bahan tersuspensi, tetapi disebabkan karena kedalaman perairan yang relatif dangkal, sebaliknya secara umum di lokasi penelitian tingkat kecerahan mencapai 80-100\% sehingga masih dalam kategori yang baik untuk budidaya laut. 
Klaster 2 terdiri dari stasiun 6,7;9-16; 19; dan 20. Klaster ini berada pada bagian tengah lokasi penelitian yaitu Kecamatan Tanjung dan Gangga dimana klaster ini dicirikan dengan karakeristik perairan memiliki suhu yang lebih hangat, salinitas lebih tinggi dan kekeruhan yang lebih rendah (Gambar 2c,d). Klaster 3 terdiri stasiun 17, 18, dan 21-23. Klaster 3 ini dicirikan dengan karakteristik perairan memiliki nilai kecerahan yang tinggi, kadar nitrat dan fosfat yang lebih tinggi (Gambar 2b,g,h).

Penggunaan CA dalam pemantauan lingkungan perairan dan mempelajari karakteristik kawasan telah banyak dilakukan (Isce et al., 2008; Radiarta et al., 2013; Radiarta dan Elina, 2015), dengan menggunakan CA akan memberikan gambaran yang baik dalam rangka mendesain lokasi pengamatan secara efisien dan efektif sesuai dengan karakteristik perairan. Selain itu, hasil CA dapat digunakan dalam penentuan tingkat kesesuaian perairan untuk pengembangan budidaya laut (Radiarta et al., 2017).

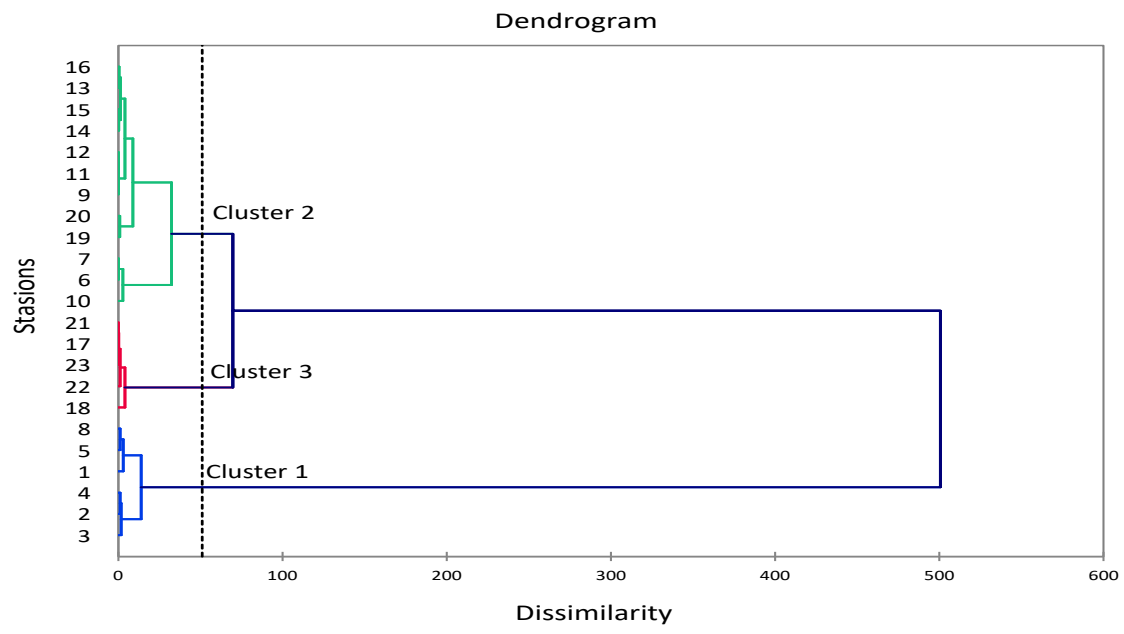

Gambar 3. Dendogram pengelompokkan lokasi penelitian berdasarkan kualitas perairan di Kabupaten Lombok Utara, Nusa Tenggara Barat

Analisis komponen utama (PCA) digunakan untuk mengidentifikasi 8 parameter kualitas air yang berpengaruh terhadap 23 stasiun pengamatan. Gambar 4 menunjukkan seluruh komponen utama (PC) yang dihasilkan dari PCA. Dari total PC yang dihasilkan tersebut, hanya tiga PC yang berperan penting yaitu F1-F3, dengan total persentase kumulatif mencapai $62,5 \%$ dari ragam total (Tabel 2). Pemilihan tiga komponen ini berdasarkan nilai akar ciri (eigenvalue) yang lebih besar dari 1. Nilai akar ciri memberikan ukuran tentang pentingnya komponen utama. Nilai akar ciri tertinggi adalah yang paling signifikan mewakili karakteristik perairan (Iscen et al., 2008; Radiarta et al., 2013; Radiarta dan Erlania, 2015). Sebaliknya nilai akar ciri yang kurang dari 1, komponen ini dinyatakan tidak dapat menjelaskan variabel dengan baik, sehingga tidak diikutkan dalam pembentukkan variabel.

Liu et al. (2003) mengelompokkan hasil PCA menjadi tiga kelompok berdasarkan nilai muatan PC (factor loading) yaitu kuat (>0,75); sedang (0,50-0,75); dan lemah $(0,30-0,50)$. Berdasarkan pengelompokkan tersebut, hasil PCA terhadap seluruh parameter kualitas perairan pada penelitian ini hanya memperhatikan kategori kuat dan sedang (Tabel 3). PC1 memiliki nilai akar ciri sebesar 2,05 dan kontribusi25,64\% dari total ragam, dibangun oleh interaksi tiga parameter utama dengan nilai muatan yang relatif besar yaitu salinitas, 
kecerahan dan fosfat dengan nilai muatan terbesar adalah salinitas yaitu sebesar 0,79. Salinitas merupakan parameter yang penting dalam aktivitas budidaya laut. Salinitas yang terlalu rendah $(<28 \mathrm{ppt})$ atau terlalu tinggi $(>35 \mathrm{ppt})$ dapat memengaruhi pertumbuhan biota budidaya laut, namun nilaiideal salinitasuntuk mendukung pertumbuhan optimal tergantung pada jenis biota yang akan dibudidaya, misalnya kerapu memiliki salinitas optimum pada kisaran 15-33 ppt (Szuster dan Albasri, 2010).

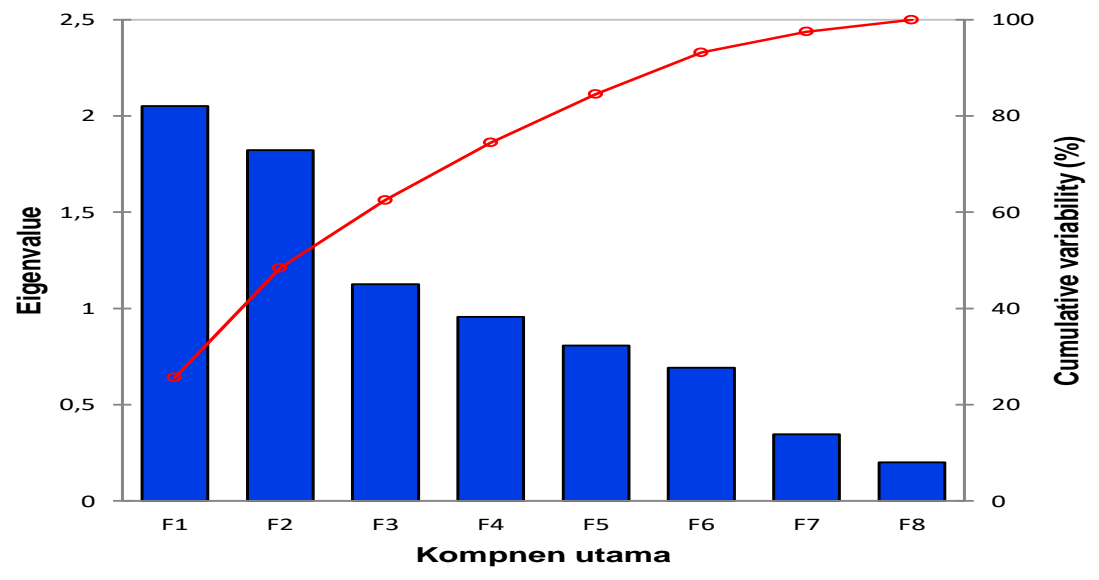

Gambar 4. Nilai akar ciri (eigenvalue) dan persentase kumulatif dari analisis komponen utama kualitas perairan di Kabupaten Lombok Utara, Nusa Tenggara Barat

Tabel 3. Hasil analisis komponen utama kualitas perairan di Kabupaten Lombok Utara Provinsi Nusa Tenggara Barat

\begin{tabular}{lccc}
\hline \multirow{2}{*}{ Variabel } & \multicolumn{3}{c}{ Komponen utama } \\
\cline { 2 - 4 } Suhu & $\mathrm{F} 1$ & $\mathrm{~F} 2$ & $\mathrm{~F} 3$ \\
Kecerahan & $-0,54$ & $-0,47$ & $-0,47$ \\
Kekeruhan & $\mathbf{0 , 3 1}$ & $\mathbf{0 , 6 0}$ & 0,15 \\
$\mathrm{pH}$ & 0,27 & $\mathbf{0 , 6 4}$ & $-0,35$ \\
Salinitas & $-0,19$ & $\mathbf{0 , 6 8}$ & $-0,02$ \\
Oksigen terlarut & $\mathbf{0 , 7 9}$ & $-0,26$ & $-0,09$ \\
Nitrat $\left(\mathrm{NO}_{3}-\mathrm{N}\right)$ & $-0,76$ & 0,13 & $-0,29$ \\
Fosfat $\left(\mathrm{PO}_{4}-\mathrm{P}\right)$ & $-0,18$ & $-0,33$ & $\mathbf{0 , 7 1}$ \\
Eigenvalue & $\mathbf{0 , 5 7}$ & $-0,43$ & $-0,40$ \\
Variability $(\%)$ & 2,05 & 1,82 & 1,13 \\
Cumulative \% & 25,64 & 22,78 & 14,08 \\
Keterangan: Nilaidengan cetak tebal $($ bold $)$ menandakannilaiKUyangkuatdansedang
\end{tabular}

PC2 memiliki nilai akar ciri sebesar 1,82 dan kontribusi22,78 \%daritotalragam, dibangun oleh interaksi tiga parameter utama dengan nilai muatan yang relatif besar yaitu kecerahan, kekeruhan dan $\mathrm{pH}$ dengan nilai muatan terbesar adalah $\mathrm{pH}$ yaitu sebesar 0,68 . Parameter $\mathrm{pH}$ merupakanparameter yangpenting dalam aktivitas budidaya lobster. Menurut FAO (1989) perairan dengan $\mathrm{pH}$ netral sampai sedikit basa merupakan perairan yang ideal 
bagi pengembangan budidaya laut berbagai komoditas. PC3 memiliki nilai akar ciri sebesar 1,13 dan kontribusi 14,08 \% dari total ragam, dibangun dalam katerogi kuat oleh parameter nitrat dengan nilai muatan terbesar adalah $\mathrm{pH}$ yaitu sebesar 0,71 . Nitrat merupakan salah satu unsur hara yang memiliki peran terhadap pembentukan sel jaringan jasad hidu organisme laut dan juga proses fotosintesi oleh fitoplankton.
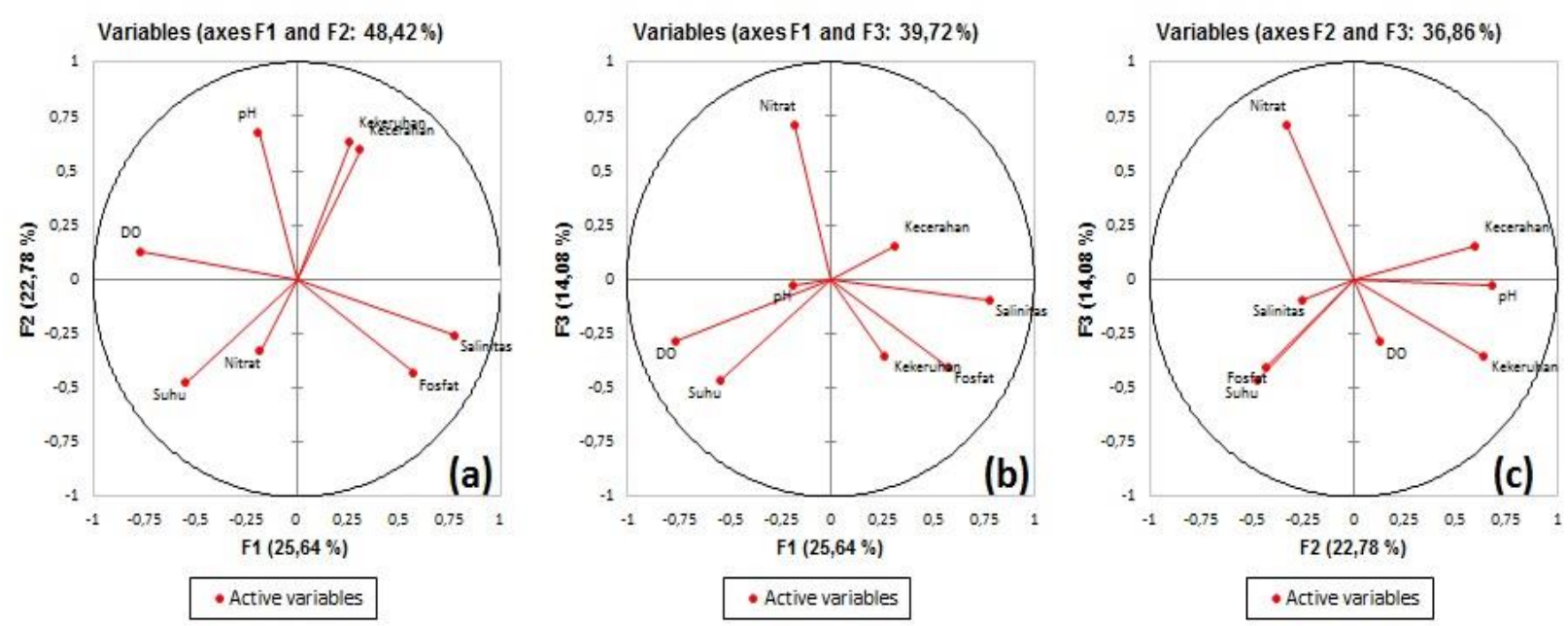

Gambar 5. Plot analisis komponen utama kondisi kualitas perairan di Kabupaten Lombok Utara Provinsi Nusa Tenggara Barat: (a) KU1 vs KU2, (b) KU1 vs KU3, (c) KU2 vs KU3

\section{KESIMPULAN}

Hasil pengukuran beberapa parameter penting menunjukkan bahwa kondisi perairan Kabupaten Lombok Utara masih memenuhi kisaran baku mutu atau nilai yang direkomendasikan untuk budidaya lobster. Berdasarkan analisis statistik multi variat yang digunakan dalam penelitian ini membagi lokasi penelitian menjadi tiga wilayah yang berbeda yaitu wilayah perairan bagian selatan yaitu sekitar Pantai Sire, wilayah bagian tengah di Kecamatan Tanjung dan Gangga dan wilayah bagian utara yang lebih berhadapan dengan laut lepas. Hasil dari penelitian ini diharapkan dapat memberikan tambahan informasi guna mendukung pengembangan budidaya lobster di Kabupaten Lombok Utara.

\section{Ucapan Terima Kasih}

Kami ucapkan terima kasih kepada Pihak Kemenristik-Dikti dan LPPM Universitas Mataram atas bantuan dana untuk menyelesaikan penelitian ini. Ucapan terima kasih juga disampaikan kepada saudara Abdul Saddam Mujib, S.Kel, M.Si., Nurul Hidayati, S.Pi., Kadek Puji, S.Pi. atas bantuan dalam pengumpulan data di lapangan sehingga penelitian ini dapat terlaksana dengan baik.

\section{DAFTAR PUSTAKA}

American Public Health Association (APHA). (2005). Standart Methods for American Public Health Association. Washington, DC.: American Public Health Association.

Arcenal, J.M.M. 2004. Sustainable farming of spiny lobster in Western Mindanao, Philippines. In Williams, K.C. Spiny lobster ecology and exploitation in the South China Sea region. Proceedings of a workshop held at the Institute of 
Oceanography. July 2004. Nha Trang. Vietnam, p. 19-20.

Basmi,J. 2000. Planktonologi: plankton sebagai bioindikator kualitas perairan. Fakultas Perikanan dan Ilmu Kelautan, Institut PertanianBogor,60hlm.

Chou, R and H.B. Lee. 1997. Commercial marine fish farming in Singapure. Aquac. Res 28:767-776.

Clark, W.A.V. and P.L. Hosking. 1986. Statistical Methods for Geographers. John Wiley \& Sons, Inc, 513 pp.

Erlania, I N. Radiarta, dan K. Sugama. 2014. Dinamika Kelimpahan Benih Lobster (Panulirus Spp.) di Perairan Teluk Gerupuk, Nusa Tenggara Barat: Tantangan Pengembangan Teknologi Budidaya Lobster. J. Ris. Akuakultur, $9(3): 475-486$

FAO. 1989. Food and Agricultural Organization. Site selection criteria for marine finfish netcage culture in Asia. Rome FAO. P 16

GESAMP (IMO/FAO/Unesco-IOC/WMO/WHO/ IAEA/UN/UNEP Joint Group of Experts on the Scientific Aspects of Marine Environ- mental Protection). 2001. Planning and man- agement for sustainable coastal aquacul- ture development. FAO Rep. Stud. GESAMP No. 68. 90 pp.

Hadi, B. (2013). Metode Interpolasi Spasial dalam Studi Geografi (Ulasan Singkat dan Contoh Aplikasinya) . Geomedia, 11 (2) , 231-240.

Holthuis, L.B. 1992. Marine lobster of the world. FAO Fisheries Synopsis, Vol.13, No. 125. FAO Rome: 139-141.

Iscen, C.F., O. Emiroglu, S. Ilhan, N. Arslan, V. Yilmaz, S. Ahiska. (2008). Application of multivariate statistical techniques in the assessment of surface water quality in Uluabat Lake, Turkey. Environmental Monitoring Assessment, 144 : 269-276., 269-276.

Ismunarti, D. (2013). Principal Component Analysis on the Relationship between Spatial Distribution of hytoplankton and Environmental Factors. ILMU KELAUTAN, 18(1), 14-19.

Jeffs, A. and M. Davis. 2003. An Assessment of the Aquaculture Potential of the Caibbean Spiny Lobster, Panulirus argus. GCFI [Gulf Caribbean Fisheries Institute], 54, 413-426.

Jones, C.M. 2010. Tropical spiny lobster aquaculture development in Vietnam, Indonesia and Australia. J. Mar. Biol. Ass. India, 52 (2) : 304 - 315, July December 2010

Junaidi, M dan A Heriati 2017. Pengembangan Budidaya Udang Karang dalam Karamba Jaring Apung Di Teluk Ekas Provinsi Nusa Tenggara Barat. Dalam T. Arifin, Yulius, E. Mustikasari, A. Heriati dan M. Ramdhan. Bunga Rampai Iptek Sumber Daya Pesisir Untuk Pengembangan Blue Economy di Pulau. IPB Press : 111-124

Junaidi, M., N. Cokrowati dan Z. Abidin. 2010. Aspek reproduksi lobster (Panulirus spp) di Perairan Teluk Ekas Pulau Lombok. Jurnal Kelautan Jurusan Ilmu Kelautan Universitas Trunojoyo, 3(1): 29-35.

Junaidi, M., N. Cokrowati dan Z. Abidin. 2011. Tingkah laku induk betina selama proses pengeraman telur dan perkembangan larva lobster pasir (Panulirus homarus). Jurnal Akuatika, 2(1): 1-10.

Junaidi, M. 2016. Pendugaan Limbah Organik Budidaya Udang Karang dalam Keramba Jaring Apung terhadap Kualitas Perairan Teluk Ekas Provinsi Nusa Tenggara Barat. J. Biologi Tropis, 16 (2) ; 64-79.

Junaidi, M., Nurliah, M. Marzuki, N. Cokrowati, I. Rahman. 2018. Identifikasi lokasi peraairan untuk pengembangan budidaya laut di Kabupaten Lombok 
Utara. Jurnal Biologi Tropis, 18 (1), 57 - 69.

Kementerian Kelautan dan Perikanan (KKP). 2014. Blue economy: pembangunan kelautan dan perikanan berkelanjutan. Kementerian Kelautan dan Perikanan. $240 \mathrm{hlm}$.

Liu, C.W., K.H. Lin and Y.M. Kuo. 2003. Application of factor analysis in the assessment of groundwater quality in a Blackfoot disease area in Taiwan. Science of the Total Environment, 313, 77-89.

MENLH (Menteri Negara Lingkungan Hidup). (2004). Surat Keputusan Menteri Negara Lingkungan Hidup No.KEP-51/MENLH/ 2004 tentang Baku Mutu Air Laut untuk Biota Laut, Lampiran III.

Morain, S. (1999). GIS Solution in Natural Resource Management: Balancing the echnical-Political Equation . USA.: OnWord Press. .

Mustafa, A. 2013. Budidaya Lobster (Panulirus sp.) di Vietnam dan Aplikasinya Di Indonesia. Media Akuakultur, 8 (2) : 73-84

Paiki, K. dan J. D. Kalor. 2017. Distribusi Nitrat dan Fosfat Terhadap Kelimpahan Fitoplankton di Peraiaran Pesisir Yapen Timur. J. of Fisheries and Marine Sciencem, 1 (2), 65-71.

Priyambodo, B. and S. Jaya. 2009. Lobster Aquaculture in Eastern Indonesia. Part 1. Methods Evolve for Fledgling Industry. In: Global Aquaculture Advocate, vol. St Louis, Missouri, USA, Global Aquaculture Alliance, p. 36-40

Priyambodo, B. and Sarifin. 2009. Lobster aquaculture industry in eastern Indonesia: present status and prospects. In: K. C. Williams (Ed.), Proceedings of an International Symposium on Spiny Lobster Aquaculture in the Asia-Pacific Region, Australian Centre for International Agricultural Research, Canberra, p. 36-45.

Radiarta, I N., Hasnawi dan A. Mustafa. 2013. Kondisi Kualitas Perairan Di Kabupaten Morowali Provinsi Sulawesi Tengah: Pendekatan Spasial dan Statistik Multivariat. J. Ris. Akuakultur, 8 (2), 299-309.

Radiarta, I.N. dan Erlania. 2015. Analisis Spasial dan Temporal Kondisi Kualitas Perairan Melalui Pendekatan Statistik Multivariat Di Teluk Gerupuk. J. Riset Akuakultur, 10 (3), 435-447.

Romimohtarto, K. dan S. Juwana. 2007. Biologi Laut Ilmu Pengetahuan tentang Biologi Laut. Edisi III. Penebit Djambatan. Jakarta. 540 hal.

Simanjuntak, M. (2009). The corelation of environment factor chemistry, physics on plankton. J. Fish. Sci., 11 (1), 31-45.

Siregar, V.P. and M.B. Selamat. (2009). Interpolator in Bathymetric Map Contouring. E-Jurnal Ilmu dan Teknologi Kelautan Tropis, 1 (1), 39-47.

Soedibjo, B. (2008). Analisis Komponen Utama Dalam Kajian Ekologi. Oseana, 13 (2), 43-53.

Szuster, W.B. And H. Albasri. 2010. Site selection for grouper mariculture in Indonesia. Int. J.Fish. Aquac, 2(3): 87-92.

Thao, N.T.K. 2012. Opportunities and challenges in lobster marine aquaculture in Viet Nam: The case of Nha Trang Bay. Thesis. The Norwegian College of Fishery Science University of Tromso, Norway \& Nha Trang University. Vietnam, 66 pp. 